\title{
The endemic that never was - resolving the status of Coprosma solandri (Rubiaceae)
}

\author{
P.J. de Lange ${ }^{1}$, M.F. Large ${ }^{1}$, L. Shepherd ${ }^{2}$, J.R. Rolfe ${ }^{3}$ \\ \& R.O. Gardner ${ }^{4}$ \\ ${ }^{1}$ School of Environmental and Animal Sciences, Unitec Institute \\ of Technology, Private Bag 92025, Victoria Street West, \\ Auckland 1142, New Zealand \\ pdelange@unitec.ac.nz \\ ${ }^{2}$ Museum of New Zealand Te Papa Tongarewa, \\ PO Box 467, Wellington 6011, New Zealand \\ ${ }^{3}$ Biodiversity Group, Department of Conservation, \\ PO Box 10420 Wellington 6143, New Zealand \\ ${ }^{4}$ Auckland War Memorial Museum, Private Bag 92018, \\ Auckland 1030, New Zealand
}

\begin{abstract}
Coprosma solandri, an enigmatic species known only from the type collection, was described in 1897 by New Zealand botanist Thomas Kirk, based on material included in a duplicate set of Banks \& Solander specimens, sent at Kirk's request, by the Natural History Museum (BM) in London to the Colonial Museum in Wellington in 1895. Here we revisit Coprosma solandri concluding that the specimens on which that name was based were not collected in New Zealand. We conclude the type of Coprosma solandri was derived from Hawaiian material of $C$. ernodeoides A.Gray that was accidentally sent to New Zealand on the assumption that Banks \& Solander had collected it from there. Although available evidence precludes definite linkage to a specific collector, we raise the possibility that the original material derives from an Archibald Menzies collection made in 1793 in Hawai'i. The recognition that Coprosma solandri and C. ernodeoides are conspecific finally removes a puzzling Coprosma from the New Zealand flora 122 years after it was described and accepted uncritically as an endemic to that country.
\end{abstract}

Keywords. Banks \& Solander, Coprosma ernodeoides, Hawai'i, New Zealand, Rubiaceae, Thomas Kirk.

\section{Introduction}

When Thomas Kirk was commissioned in 1894 to prepare a New Zealand Flora by the New Zealand Government, he requested that a set of the plants collected by Banks \& Solander be sent to New Zealand (Adams, 1988; Brownsey, 2012). This duplicate set was received in 1895, from the Banks \& Solander herbarium at the then British Museum of Natural History, by the then Colonial Museum in Wellington. 
Among those collections, Kirk located a Coprosma that he could not match with any known New Zealand species. That material, comprising several sterile and fruiting branches, lacked location details. Nevertheless, on the assumption that it was collected from New Zealand, Kirk described it as a new species, Coprosma solandri Kirk. Kirk further suggested that Coprosma solandri was possibly collected from the 'East Cape district' of the North Island (Kirk, 1897, 1899). Why he suggested this is unclear. Banks \& Solander were able to collect at eight coastal locations - six eastern North Island, two northern South Island (Brownsey, 2012). Kirk also suggested that Coprosma solandri is related to $C$. colensoi Hook.f. and C. linariifolia Hook.f. However, neither of those species closely matches the morphology of Coprosma solandri, though $C$. linariifolia has superficially similar connate stipules which form a distinctive tubular sheath quite unlike any other New Zealand species (Oliver, 1935; Allan, 1961).

Subsequent treatments of New Zealand Coprosma have struggled to place $C$. solandri. Cheeseman $(1906,1925)$ accepted it, noting that he did so in the absence of specimens used by Kirk, but that 'there are specimens...in the set of Banksian plants presented to my own herbarium from the same source. Unfortunately, they are not in flower, but the aspect of the plant appears to resemble that of Coprosma linariifolia' (Cheeseman, 1925: 872). Oliver (1935) also accepted Coprosma solandri, though somewhat reluctantly, as he stated that the specimens on which it was based could not be located. In the last full treatment of New Zealand Coprosma, Allan (1961: 586) treated the species as "Incertae Sedis"; his assessment combining the comments of Kirk, Cheeseman and Oliver.

Other than these statements, the only other comment we can find on the species was made on the original Kirk material, which, despite Cheeseman's and Oliver's statements, is now lodged in WELT (Herbarium acronyms follow the Index Herbariorum (Thiers, continuously updated) (Fig. 1). On that sheet (WELT SP063854) the late A.P. (Tony) Druce (1920-1999), who was at the time engaged in an ultimately unpublished revision of New Zealand Coprosma, added the comment dated 4 August 1978 "not like any other N.Z. sp[ecies] — probably not collected in N.Z. (possibly not Coprosma, but definitely Rubiaceae)". Oddly Druce - a noted Coprosma expert seems to have given the species no more thought, $C$. solandri being absent from his subsequent numerous, unpublished Coprosma compendia, checklists and assessments of the New Zealand Flora.

Here we revisit Coprosma solandri concluding that Druce was correct: the specimens on which that name was based were not collected in New Zealand. However, Coprosma solandri is indeed a Coprosma and is in fact conspecific with the Hawaiian endemic C. ernodeoides A.Gray. 


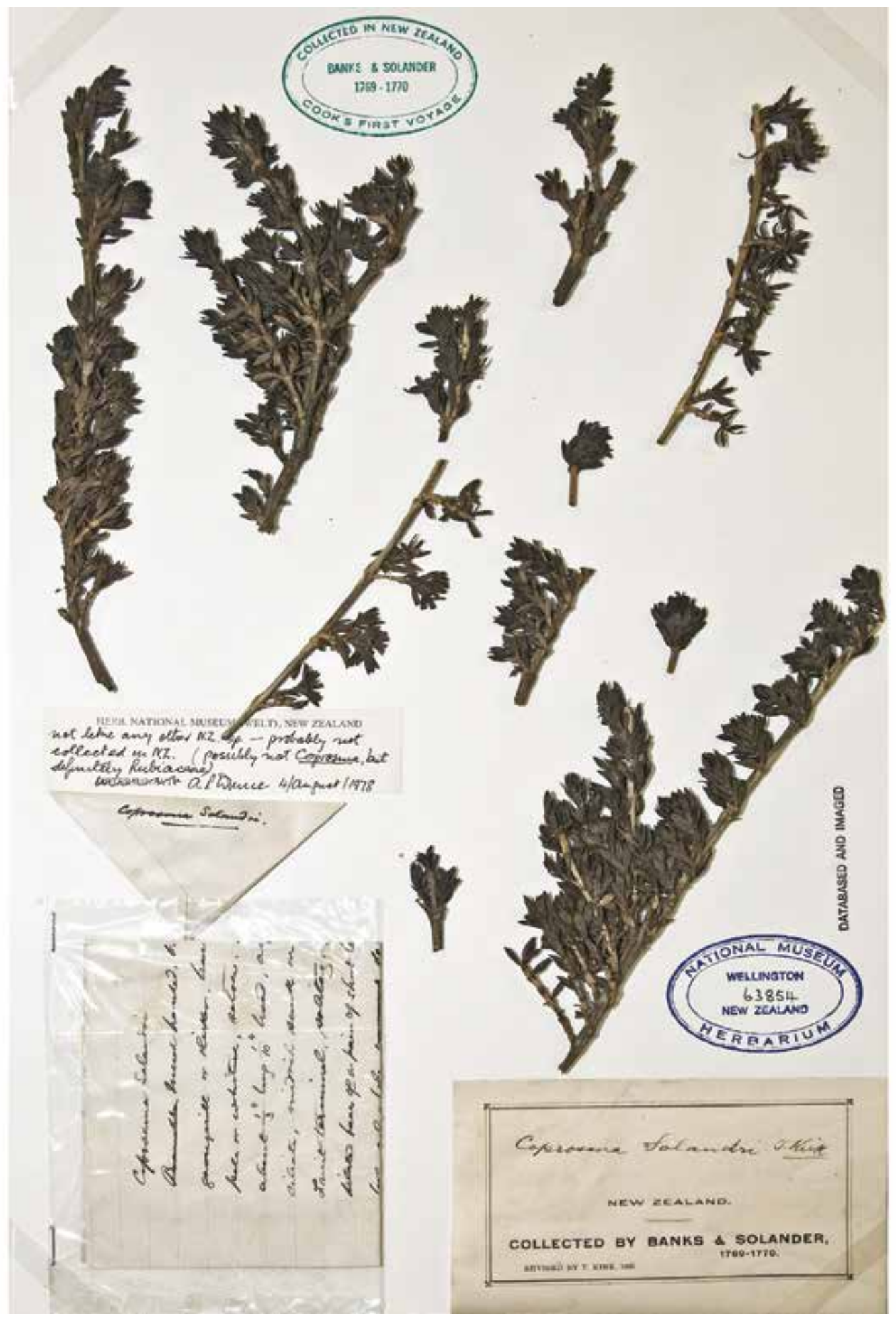

Fig. 1. Holotype of Coprosma solandri. From WELT SP063854. 


\section{Taxonomy}

Coprosma J.R.Forst. \& G.Forst. Char. Gen. Pl., ed. 2., 137 (1776). - TYPE: Coprosma foetidissima J.R.Forst. \& G.Forst., lectotype designated by Oliver (1935).

Coprosma is a Pacific Ocean-centred genus of over 110 species of trees and shrubs (Oliver, 1935; Van Balgooy, 1966; Van Royen, 1983; Gardner, 2002; Utteridge, 2002). The genus is distributed in temperate and montane-tropical regions from Borneo southeast to Australia, New Zealand, and associated subantarctic islands, and across the Pacific Ocean to Hawai' $i$ and Juan Fernandez Islands. The centre of diversity for the genus lies within New Zealand (Oliver, 1935; Heads, 1996), where there are c. 50-55 taxa formally recognised (Eagle, 2006; Dawson, 2000; de Lange \& Gardner, 2002; de Lange et al., 2002; Norton \& de Lange, 2003; Jane, 2005) and at least a further seven entities awaiting formal recognition (Eagle, 2006; P.J. de Lange, unpubl. notes).

Coprosma solandri Kirk, Trans. \& Proc. New Zealand Inst. 29: 522 (1897). - TYPE: 'Collected by Banks \& Solander 1769-1770' (holotype WELT SP063854!).

Description of holotype. Main branches 2-4(-8) mm diameter, arching or straight and tapering, prostrate or trailing (?); lateral shoots decussate, numerous, usually arched or ascending, short, 15-20(-90) mm long. Mature branches grey-brown or brown glabrous. Juvenile shoots slender, up to $1 \mathrm{~mm}$ diameter, initially \pm tetragonoussubterete, maturing tetragonous; outer bark chartaceous, whitish, densely covered in fine, hispid, hairs $0.6-0.8(-1.0) \mathrm{mm}$ long, patent, bark flaking in small tabular shards exposing firmer, glabrous, grey-brown under bark. Brachyblasts initiating at the apex of penultimate flush, leaves densely aggregated, expanded, the rest of the brachyblast covered in sheathing tubular stipules. Leaves opposite, coriaceous (fleshy when fresh?), sessile to very shortly petiolate, petioles $0.3-0.5 \mathrm{~mm}$ long, articulated to stem; lamina (5.0-)8.0-10.0(-10.2) × 2.0-3.0(-3.5) $\mathrm{mm}$, narrowly lanceolate, smooth, apex acute, base \pm attenuate, or abruptly terminated at petiole / stem junction; midrib deeply immersed abaxially and adaxially, lateral veins not evident, lamina margins slightly thickened, initially furnished with widely spaced, stout, patent to weakly antrorse arching hairs, mature leaves usually glabrous or glabrescent. Stipules orbicular, (1.0)1.5-2.0 $\mathrm{mm}$ long, 3-4(-6) $\mathrm{mm}$ wide at apex, tubular-sheathing, connecting at bases with leaves, otherwise terminating orbicular apex; margins and surface finely dentate to smooth, sparse to \pm densely covered in $0.1-0.3 \mathrm{~mm}$ long hispid hairs, these pale, patent across stipule surface, where they are usually often denser centrally; distally hairs \pm antrorse-appressed and \pm concealing (1-)3 dark, glandular denticles at the stipule apex. Flowers not seen. Drupes immature, these terminal and solitary, ovoid, ellipsoid to subglobose 5-6 $\times 4-5 \mathrm{~mm}$, calyx-lobes persistent, epidermis of drupe smooth. 
Remarks. Despite the comment by Cheeseman (1925) that he had further specimens of Coprosma solandri 'from the same source' that were of 'Banksian origin' and which had been 'presented to [his] own herbarium', there are none in AK. It is known that Cheeseman, whilst engaged in writing his Flora of New Zealand, did take specimens from WELT (de Lange, 2016) to Auckland, and that these were held and sometimes incorporated in his herbarium following his death in 1923 . Therefore, we suspect that 'Cheeseman's' specimens were in fact the original material of Coprosma solandri borrowed from WELT and not returned to there until several decades after Cheeseman's death, when his herbarium was fully incorporated into what is now AK by the then curator Lucy Cranwell. If correct, this would explain Oliver's comment that he could not find the specimens in WELT on which Coprosma solandri was based (Oliver, 1935).

\section{Identity of Coprosma solandri}

The distinctive nature of Coprosma solandri in the New Zealand flora is beyond doubt; none of the formal accounts of New Zealand Coprosma have reduced it to synonymy, all have accepted it (Kirk, 1899; Cheeseman, 1906, 1925; Oliver, 1935; Allan, 1961). Only Druce, somewhat presciently in his specimen annotation, suggested that the species was not of New Zealand origin. Intriguingly the World Checklist of Selected Plant Families (Govaerts, 2003) treats Coprosma solandri as a synonym of $C$. linariifolia (Govaerts, 1999, 2003) though on what basis is not clear.

The idea that Coprosma solandri is not of New Zealand derivation has some precedence. For example, another species, Olearia buchananii Kirk, was also described by Kirk (1899) from a unicate gathering he had assumed came from New Zealand (Gardner et al., 2001). That species is now treated as a synonym of the Australian endemic Olearia viscosa (Labill.) Benth., with the assumption that the type of $O$. buchananii was either a garden-grown plant of Australian origin collected in Wellington, or based on herbarium exchange material from Australia (Gardner et al., 2001).

On the assumption that the original 'Banks \& Solander' material on which Coprosma solandri was based came from elsewhere, we looked for a match in the genus outside New Zealand. Using Oliver (1935) as a starting point we found that the closest counterpart for Coprosma solandri is the Hawaiian endemic $C$. ernodeoides, with which it shares the same apparent growth habit, with long, tapering many-branched stems bearing numerous short, ascending, lateral branches, initially tetragonous (angled) hispidulous branchlets, leaf shape, and tubular-sheathing stipules with hispidulous, finely dentate to smooth margins which are adnate to the leaf bases typical of Hawaiian specimens of C. ernodeoides we examined e,g. J.W. Dawson s.n., 23 May 1983, Mauna Loa, Hawai'i (WELT), and the description of this species in the Hawaiian Flora (Wagner et al., 1990) (Fig. 2). Although flowering material is absent in the type of Coprosma solandri, the fruits of both species agree in that both have the characteristic persistent calyces of C. ernodeoides (Wagner et al., 1990). 


\section{DNA analysis}

Beyond the morphological similarity between Coprosma ernodeoides and C. solandri we also attempted to obtain DNA sequence data from the type of Coprosma solandri.

Five leaves were removed from the Coprosma solandri herbarium sheet, placed in a $1.7 \mathrm{ml}$ microcentrifuge tube and taken to an ancient-DNA laboratory for processing. The leaf tissue was ground to a fine powder in the microcentrifuge tube with a sterile pestle. ADNA extraction was performed with a Dneasy plant mini kit (Qiagen, Valencia, CA, USA). A negative extraction control containing no leaf tissue was processed in parallel with the Coprosma solandri sample to monitor for reagent contamination. The manufacturer's instructions were followed except that incubation was for 1 hour and the final elution used $45 \mathrm{ml}$ Buffer AE. PCRs were set up in the ancient-DNA laboratory before being transported to a modern-DNA laboratory for amplification. A negative PCR control containing no added DNA was included in each batch of PCRs, as well as the negative DNA extraction control. A positive control of modern Coprosma robusta Raoul DNA was added to each batch of PCRs in the modern laboratory to confirm the ability of the novel primers to amplify their targets. PCRs were performed in 1 ' Mytaq mix (Bioline, Australia), 5 pmol of each primer and $15 \mu \mathrm{g}$ bovine serum albumin. Novel primers were designed from published Coprosma nuclear internal transcribed spacer (ITS) sequences (Cantley et al., 2016) to target autapomorphies for C. ernodeoides. CoprosmaITS1F (5'-CGCCAAGGACTACTCAAACG-3') and CoprosmaITS1R (5'-AGCCTAGATATCCGTTGCCG-3') amplify a 109 bp fragment and CoprosmaITS2F (5'-TCATAAACTGACCGGGCGAC-3') and CoprosmaITS2R (5'-GCCGTGAGTTTAGTTGGGTC-3') amplify a 60 bp fragment. We also amplified the P6 loop of the chloroplast trnL (UAA) intron, which is 43 bp in length in Coprosma, using the $g$ and $h$ primers of Taberlet et al. (2007). For all PCR amplifications the thermocycling conditions were an initial denaturation of 2 minutes at $94^{\circ} \mathrm{C}$, followed by 35 cycles of $94^{\circ} \mathrm{C}$ for 20 seconds, $50^{\circ} \mathrm{C}$ for 20 seconds and $72^{\circ} \mathrm{C}$ for 30 seconds; followed by a final extension of 5 minutes at $72^{\circ} \mathrm{C}$.

PCR products were visualised by electrophoresis on a $2 \% \mathrm{MS} / 1 \% \mathrm{LE}$ agarose gel. Unfortunately, the positive control DNA amplified for all three loci but the negative extraction and PCR controls did not produce amplification products and neither did the Coprosma solandri extract.

\section{Discussion}

Although we were unable to extract DNA from the type specimen, the morphological similarity between Coprosma ernodeoides and C. solandri specimens and descriptions is clear; there are no other Coprosma species which C. solandri resembles (Oliver, 1935) and so we consider that the identity of Coprosma solandri has finally been resolved. However, the question remains how a Hawaiian endemic ended up in a consignment of New Zealand collected Bank \& Solander specimens sent to New Zealand. 


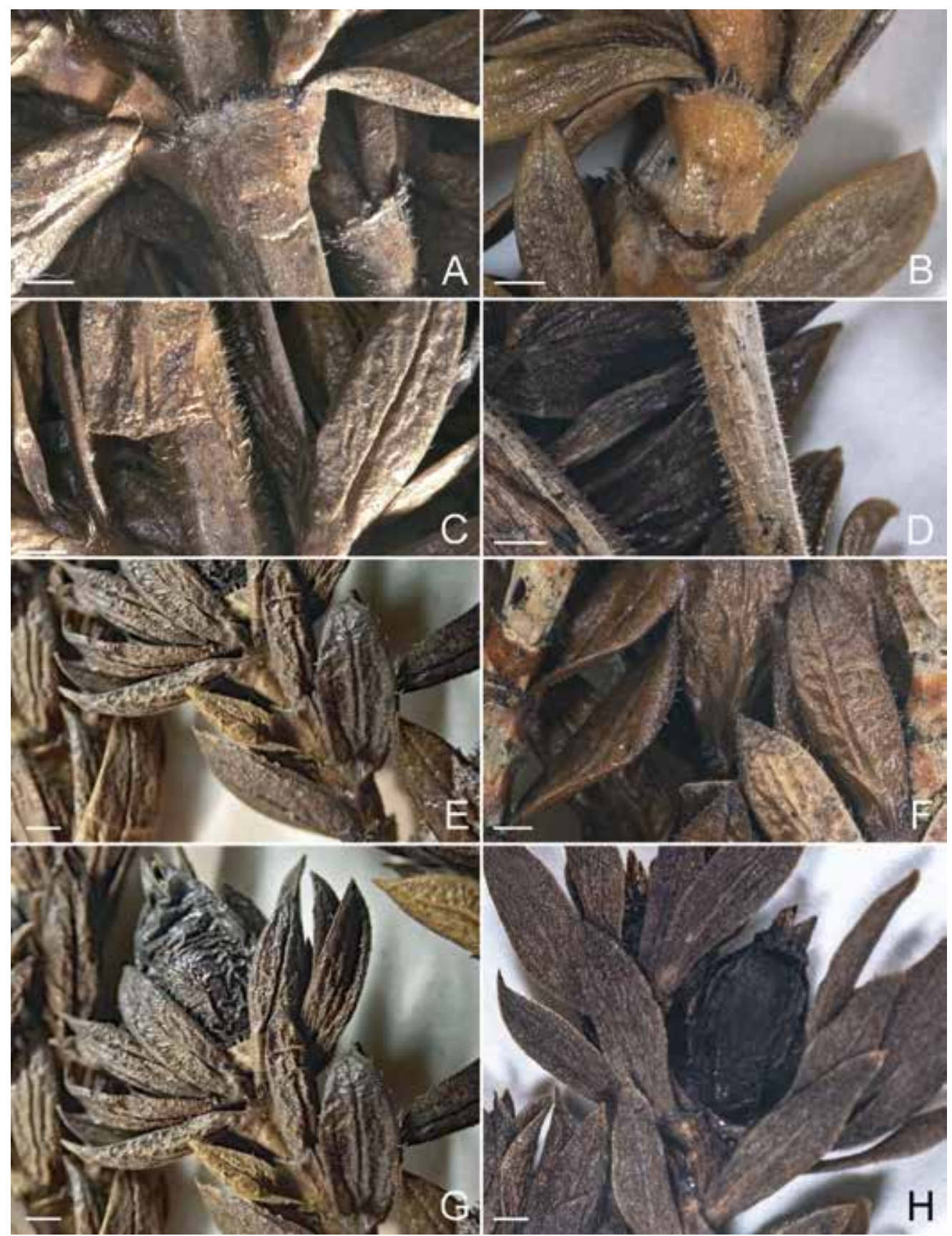

Fig. 2. Comparison of the holotype of Coprosma solandri with $C$. ernodeoides. A, $\mathbf{C}, \mathbf{E} \boldsymbol{\&} \mathbf{G}$. C. solandri. A. Stipule. C. Stem hairs. E. Leaf hairs. G. Fruit. B, D, F \& H. C. ernodeoides. B. Stipule. D. Stem hairs. F. Leaf hairs. H. Fruit. Scale bars $=1 \mathrm{~mm}$. B, D, F \& H from J.W. Dawson s.n (WELT). (Photos: A-D \& F-H, J. R. Rolfe; E \& G, P.J. de Lange). 
We know that Joseph Banks acquired herbarium specimens from a range of collectors. Notably from the Hawaiian Islands he obtained material collected by David Nelson on Cook's Third Voyage (St John, 1978) and Archibald Menzies (Gray, 1860; Newcombe \& Forsyth, 1923). St John (1978) has enumerated the Hawaiian plants observed or collected by Nelson, and of those specimens extant within the Banks Herbarium there are only two Coprosma - C. pubens Gray and C. rhynchocarpa Gray. However, Menzies, who was appointed to the Vancouver expedition on Bank's recommendation (Newcombe \& Forsyth, 1923) obtained the type material of Coprosma ernodeoides during his 1793 or possibly, 1794 visits to Mauna Loa, Hawai'i (Gray, 1860 c.f. Barnard, 1991). So, if the type of Coprosma solandri truly came from the Banks Herbarium it seems likely that it was some of this collection. Alternatively, the type material may have come from other Coprosma ernodeoides collections housed at BM that were accidentally included in the Banks \& Solander duplicates sent to New Zealand. Indeed, there is a mixed sheet in BM (Fig. 3) that includes three collections of this species. Two small branches collected by Menzies himself in 1793, material collected in 1870 by W. Hillebrand from 'Haleakalā 5000ft' 'E Maui', and material collected in 1825 'Ins. Owhyhee ad montem ignivomen. Macrae'. Unfortunately, for now we cannot offer anything further as to the likely source in BM of the type of Coprosma solandri.

Irrespective of who collected the specimens destined to become Coprosma solandri, that enigmatic species can after 122 years now be removed from the New Zealand indigenous flora and placed as a synonym of the Hawaiian endemic $C$. ernodeoides.

DEDICATION AND ACKNOWLEDGEMENTS. We dedicate this paper to David Mabberley, last $\mathrm{PhD}$ student of the renowned Professor Corner, whose love of plants, myriad insightful publications, interest in the flora of the Southern Hemisphere, and enthusiastic support of Australasian botany has been a leading light directing the careers of the authors.

We would also like to thank Dr Leon Perrie, curator of the herbarium (WELT), Te Papa Tongarewa Museum of New Zealand, for permission to study, take images of, and sample for our attempted DNA sequencing of the type of Coprosma solandri and C. ernodeoides. We also thank Mr Ewen Cameron, curator, Auckland Museum Herbarium (AK) for access to Cheeseman specimens and notes held under his care; Serena Marner, Plant Sciences Oxford for her advice concerning early collections, and Dr Mark Carine, Natural History Museum London, for his assistance in finding the Archibald Menzies material. 


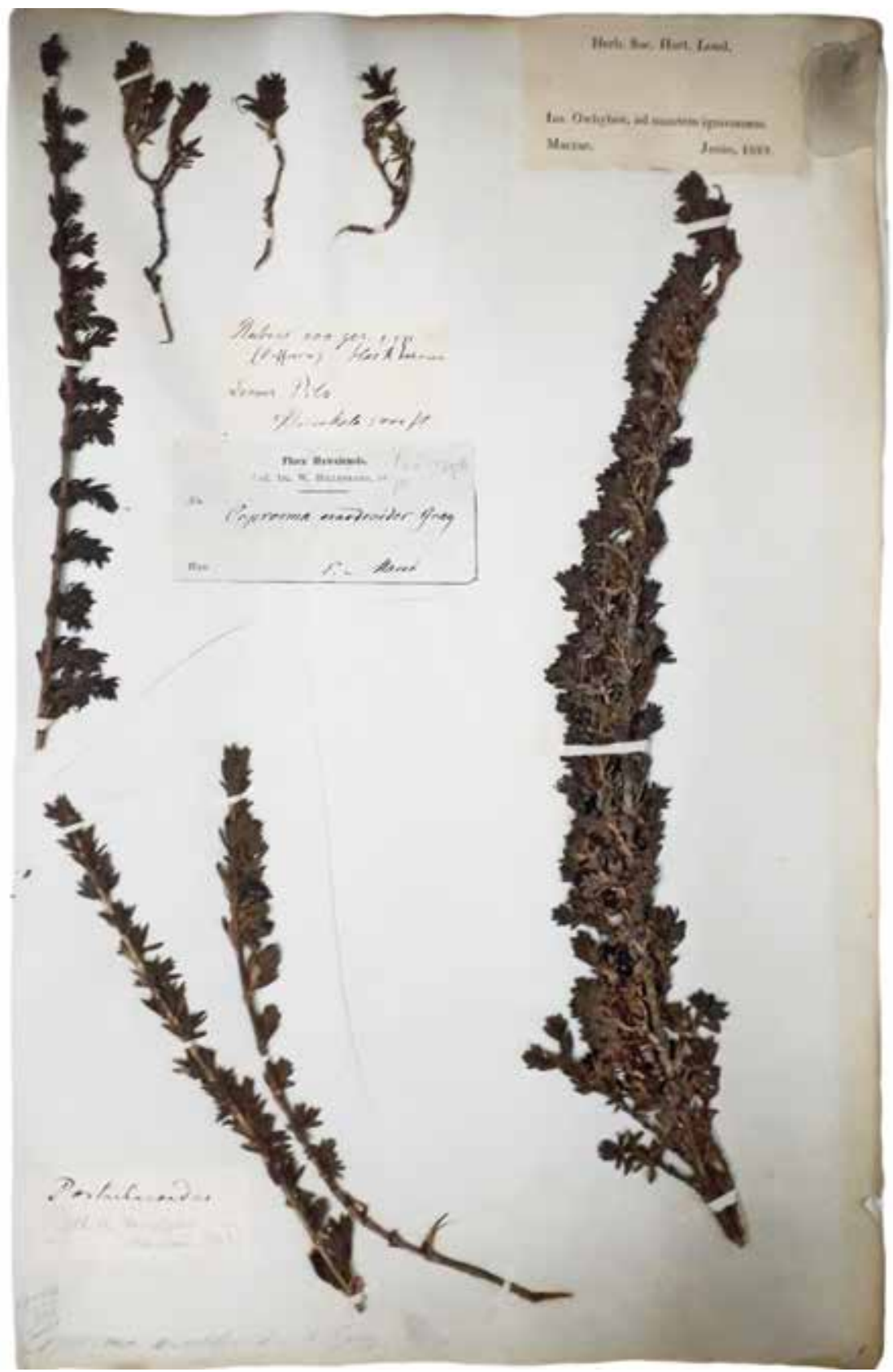

Fig. 3. A sheet in BM that holds three collections of Coprosma ernodeoides, including two small branches collected by Archibald Menzies in 1793. 


\section{References}

Adams, N.M. (1988). The first illustrations of New Zealand plants: The Banks and Solander proofs held in New Zealand. Natl. Mus. New Zealand Rec. 3: 93-99.

Allan, H.H. (1961). Flora of New Zealand, vol. 1. Wellington: Government Printer.

Barnard, W.M. (1991). Earliest ascents of Mauna Loa volcano, Hawai'i. The Hawaiian Journal of History 25: 53-70.

Brownsey, P.J. (2012). The Banks and Solander collections - a benchmark for understanding the New Zealand flora. J. Roy. Soc. New Zealand 42: 131-137.

Cantley, J.T., Markey, A.S., Swenson, N.G., \& Keeley, S.C. (2016). Biogeography and evolutionary diversification in one of the most widely distributed and species rich genera of the Pacific. AoB Plants 8: plw043.

Cheeseman, T.F. (1906). Manual of the New Zealand Flora. Wellington: Government Printer.

Cheeseman, T.F. (1925). Manual of the New Zealand Flora, $2^{\text {nd }}$ ed. Wellington: Government Printer.

Dawson, M.I. (2000). Index of chromosome numbers of the indigenous New Zealand spermatophytes. New Zealand J. Bot. 38: 47-150.

de Lange, P.J., \& Gardner, R.O. (2002). A taxonomic reappraisal of Coprosma obconica Kirk (Rubiaceae: Antherospermeae). New Zealand J. Bot. 40: 25-38.

de Lange, P.J., Gardner, R.C., Wright, S.D., \& Wichman, S.R. (2002). A new combination for a Coprosma endemic to the serpentinised zone of the Surville Cliffs, North Cape, New Zealand. New Zealand J. Bot. 40: 521-522.

de Lange, P.J. (2016). When labels get mixed - lessons to be learned from a study of the Thomas Kirk 'herbarium' and historical Simplicia collections. Trilepidea 152: 1-11.

Eagle, A. (2006). Eagle's complete trees and shrubs of New Zealand. Wellington: Te Papa Press.

Gardner, R.O., de Lange, P.J. \& Fox, J.M. (2001). Identity of Olearia buchananii (Asteraceae). New Zealand J. Bot. 39: 209-215.

Gardner, R.O. (2002). The genus Coprosma (Rubiaceae) in New Guinea. Candollea 57: 97-130.

Govaerts, R. (1999). World Checklist of Seed Plants 3(1, 2a \& 2b): 1-1532. MIM, Deurne. [as Unplaced Name]

Govaerts, R. (2003). World Checklist of Selected Plant Families Database in ACCESS: 1-216203. The Board of Trustees of the Royal Botanic Gardens, Kew. [as Unplaced Name]. https://wcsp.science.kew.org. Accessed 8 May 2019.

Gray, A. (1860). Notes upon some Rubiaceae, collected in the United States South-Sea Exploring Expedition under Captain Wilkes, with characters of new species, etc. Proc. Amer. Acad. Arts 4: 35-50.

Heads, M.J. (1996). Biogeography, taxonomy and evolution in the Pacific genus Coprosma (Rubiaceae). Candollea 51: 381-405.

Jane, G.T. (2005). An examination of Coprosma ciliata and C. parviflora complex. New Zealand J. Bot. 43: 735-752.

Kirk, T. (1897). On the botany of the East Cape District. Trans. \& Proc. New Zealand Inst. 29: 509-532.

Kirk, T. (1899). The Students' Flora of New Zealand and the Outlying Islands. Wellington: Government Printer. 
Newcombe, C.F. \& Forsyth, J. (eds) (1923). Menzies' journal of Vancouver's voyage, April to October, 1792, edited, with botanical and ethnological notes and a biographical note. Victoria (British Columbia): William H. Cullen Printer.

Norton, D.A., \& de Lange, P.J. (2003). A new species of Coprosma (Rubiaceae) from the South Island, New Zealand. New Zealand J. Bot. 41: 223-231.

Oliver, W.R.B. (1935). The genus Coprosma. Bull. Bernice P. Bishop Mus. 132: 1-207.

St John, H. (1978). Plants of the Sandwich Islands collected by Archibald Menzies. Phytologia 38: $1-6$.

Taberlet, P., Coissac, E., Pompanon, F., Gielly, L., Miquel, C., Valentini, A., Vermat, T., Corthier, G., Brochmann, C. \& Willerslev, E. (2007). Power and limitations of the chloroplast $\operatorname{trn} \mathrm{L}$ (UAA) intron for plant DNA barcoding. Nucl. Acids Res. 35: e14.

Thiers, B. (continuously updated). Index Herbariorum: A global directory of public herbaria and associated staff. New York Botanical Garden. http://sweetgum.nybg.org/science/ih. Accessed 29 March 2019.

Utteridge, T.M.A. (2002). New species of Coprosma (Rubiaceae) from New Guinea. Contributions to the Flora of Mt Jaya VII. Kew Bull. 57: 195-203.

Van Balgooy, M.M.J. (1966). Coprosma. Pacific plant areas. Blumea, Suppl. 5: 76-77.

Van Royen, P. (1983). Alpine Flora of New Guinea; Coprosma and Nertera. Vaduz: Cramer.

Wagner, W.L., Herbst, D.R., \& Sohmer, S.H. (1990). Manual of the Flowering Plants of Hawai’i, vol. 2, Bishop Museum Special Publication 83. Honolulu: Bishop Museum. 
